This is an Accepted Manuscript of an article published by Taylor \& Francis Group in Intellectual History Review on 24/9/2012, available online:

http://www.tandfonline.com/10.1080/17496977.2012.723343

\title{
Philosophers, Naturalists, and Antipodean Encounters, 1748-1803
}

\author{
Bronwen Douglas \\ The Australian National University
}

\begin{abstract}
This paper addresses a complex nexus of discourse and praxis: varying Enlightenment visions of Man; emergent ideas about human differences; and encounters between European scientific voyagers and Indigenous people in New Holland (Australia) and Van Diemen’s Land (Tasmania) at the start of the 19th century. Discursively, I trace two strands of 'anthropological' thinking. One, philosophical and economic, is epitomized in French and Scottish stadial theory. The other is naturalist and culminated in Buffon's natural history of man. Both were appropriated from the late 18th century by a nascent science of race. With respect to praxis, I chart the reciprocal impact of metropolitan theory, antipodean experience, and local agency by selective comparison of materials produced by the voyages of Matthew Flinders and Nicolas Baudin in Australian waters in 1801-1803.
\end{abstract}


This paper addresses a complex nexus of discourse and praxis: varying Enlightenment visions of Man, emergent ideas about human differences, and diverse intellectual and material legacies of encounters between European scientific voyagers and Indigenous people in New Holland and Van Diemen's Land at the turn of the 19th century. Discursively, I trace two strands of 'anthropological' thinking, both indebted to the French political philosopher Montesquieu. One, philosophical and economic, is epitomized in French and Scottish stadial theory. The other is naturalist and culminated in Buffon's natural history of man with its novel focus on human varieties. Around 1800, especially in France, these divergent strands were appropriated by a nascent science of race which conceived certain 'races' as permanently stranded at the base of the human racial hierarchy or even doomed to extinction. With respect to praxis, I chart the interplay of metropolitan theory, antipodean experience, and local agency by focussing comparatively on written and visual legacies of Matthew Flinders’s and Nicolas Baudin’s austral voyages of 1801-1803.

\section{Thinking 'Man' in the late Enlightenment}

By 1700, longstanding conventional wisdom maintained, as the German polymath Leibniz put it, that 'all men' belonged to 'a single race, which has been altered by different climates'. The monogenist attribution of human variation to climate was hardly challenged during the next century, despite heretical intimations of what would eventually be called polygeny by thinkers as eminent as Hume, Voltaire, and Kames. ${ }^{2}$ Leibniz’s avowal concludes his

${ }^{1}$ G. W. Leibniz, 'Lettre de Mr. Leibniz à Mr. Sparvenfeld [1797]', in Otium Hanoveranum, sive, Miscellanea [...], edited by J. F. Feller (Lipsiae [Leipzig], 1718), 38. All translations are mine. For aesthetic reasons, I use inverted commas minimally, including them on first mention of a specialized contemporary English term and then omitting them except for direct quotations. They are consistently implied, but omitted after initial reference, in the case of now problematic terms like 'race', ‘native', ‘civilized', 'savage’, 'primitive’, 'Negro’, 'man’ (in the inclusive sense of humanity), and so forth.

${ }^{2}$ In 1753, in a notorious footnote to a new edition of his essay 'Of National Characters', Hume declared 'the negroes, and [...] all the other species of men (for there are four or five different kinds) to be naturally inferior to the whites' as a result of 'an original distinction' made by nature 'betwixt these breeds of men' (D. Hume, 'Of National Characters', in idem, Essays and Treatises on Several Subjects, vol. 1, Containing Essays, Moral and Political, fourth edition (London and Edinburgh, 1753 [1748], 277-300 (291, note *)). In 1765, Voltaire suggested that 'the Negroes' were 'specifically different' from 'the other species of 
discussion of a recent attempt to classify man 'into certain tribes, races, or classes ${ }^{3}$ - a sign of the growing recourse to collective terminology in European thinking on man and of a dawning interest in taxonomy. Group appellations and their appropriation as taxa were conceptual tools to manage the escalating influx of knowledge about human diversity. By the mid-18th century, human taxonomy was still unusual, despite the pioneering efforts of Bernier and Linnaeus. ${ }^{4}$ However, the hitherto insignificant genealogical term 'race' now figured in a set of more or less transposable collective nouns increasingly applied to broad human groupings, along with 'kind’ or 'species', 'variety', 'people’, ‘nation’, 'class', and 'tribe'. 5

Philosophical and natural historical approaches to the study of man should not be dichotomized since the great Enlightenment polymaths were attuned to both. These variant strategies are best construed as relative emphasis on political, economic, or civic differences, on the one hand, and physical differences, on the other. In 1748, Montesquieu correlated climate with national character, and subsistence practices with the relative extent of the 'code of laws', ranging from the complex code required by a commercial and maritime people to

men' because the 'prodigious' physical and intellectual differences between them, particularly Negro 'blackness' ('noirceur'), were 'inherent' and could not be explained in conventional climatic terms ([Voltaire], La philosophie de l'histoire par feu l'Abbé Bazin (Amsterdam, 1765), 5-6). Kames rejected Buffon’s climatic determinism and argued: 'were all men of one species, there never could have existed, without a miracle, different kinds, such as exist at present' (H. Home, Lord Kames, Sketches of the History of Man, 2 vols (Edinburgh and London, 1774), vol. 1, 37). I generalize the useful terms 'monogenist' and 'polygenist', invented in the mid-19th century to designate opposed positions adopted on the original unity or specific diversity of the human genus.

${ }^{3}$ Leibniz, 'Lettre', 37.

${ }^{4}$ [F. Bernier], 'Nouvelle division de la terre, par les differentes especes ou races d'hommes qui l'habitent, envoyée par un fameux voyageur à M. l'Abbé de la $* * * * *$ à peu près en ces termes', Journal des Sçavans (24 April 1684), 133-40; C. Linnaeus, Systema Naturce, sive Regna tria Naturce [...], (Lugduni Batavorum [Leiden], 1735); idem, Systema Naturce per Regna tria Naturce [...], tenth edition, 2 vols (Holmiæ [Stockholm], 1758-9), vol. 1, 20-5. ${ }^{5}$ For a semantic and discursive history of the term 'race', see B. Douglas, 'Climate to Crania: Science and the Racialization of Human Difference', in Foreign Bodies: Oceania and the Science of Race 1750-1940, edited by B. Douglas and C. Ballard (Canberra: ANU E Press, 2008), 33-96 (34-44). 
the ever simpler laws needed by agriculturalists or by 'barbarous' pastoralists and 'savage' hunters. ${ }^{6}$ From about 1750, theorists in both France and Scotland sought to explain the origins of ‘civilized society’ by historicizing these different subsistence-legal modes as 'successive changes in the lifestyle of men' and by universalizing them as a three- or fourstep ladder of progress 'from rudeness to civilization'. ${ }^{7}$ Adam Smith, who is usually credited as the originator of Scottish stadial theory, listed the 'four distinct states which mankind pass thro: $-1^{\text {st }}$, the Age of Hunters; $2^{\text {ndly }}$, the Age of Shepherds; $3^{\text {rdly }}$, the Age of Agriculture; and $4^{\text {thly }}$, the Age of Commerce'. ${ }^{8}$ Stadial thinkers saw the shift to agriculture as the key transition because it produced the 'relation of land-property'. ${ }^{9}$

The conflation of civil society with an historically-specific agricultural practice quickly became a standard trope in developmentalist theories, usually with dire implications for present Indigenous people whose lifestyles did not match the mould - particularly Aboriginal Australians and Tasmanians in expanding colonial settings after 1788. Most Scottish stadial theorists concurred that 'Man is every where the same; and [...] that the

${ }^{6}$ C.-L. de Secondat de Montesquieu, L'esprit des lois, nouvelle édition, 4 vols (London, 1777 [1748]), vol. 2, 31-60, 139-57.

${ }^{7}$ A. Ferguson, An Essay on the History of Civil Society (Edinburgh and London, 1767), 1-2; D. Stewart, 'Account of the life and writings of Adam Smith, LL.D.: from the Transactions of the Royal Society of Edinburgh', in Essays on Philosphical Subjects by the late Adam Smith, LL.D. [...], edited by J. Black and J. Hutton (London, 1795), x-xcv (xli); A.-R.-J. Turgot, 'Sur la géographie politique', in Euvres de $M^{r}$. Turgot, ministre d'état [...], [edited by P.-S. Dupont de Nemours], 9 vols (Paris, 1808-11), vol. 2, 174. On stadial or four-stages theory, see R. L. Meek, 'Smith, Turgot, and the "Four Stages” Theory', History of Political Economy 3:1 (1971), 9-27; M. S. Staum, Minerva's Message: Stabilizing the French Revolution (Montreal and Kingston: McGill-Queen’s University Press, 1996), 26-7, 152-69. ${ }^{8}$ These words were recorded in a student's notes of lectures given by Smith in 1762 (A. Smith, Lectures on Jurisprudence, edited by R. L. Meek, D. D. Raphael, and P. G. Stein (Oxford: Oxford University Press, 1978), 14. On Smith's precedence in Scottish stadial theory, see Meek, 'Smith, Turgot', 15, note 18, 16-23; Stewart, 'Account', xv-xvi, xl, xliv. ${ }^{9}$ Ferguson, An Essay, 123-4; H. Home, Lord Kames, Historical Law-Tracts, 2 vols (Edinburgh and London, 1758), vol. 1, 144-6; J. Millar, The Origin of the Distinction of Ranks [...], third edition (London, 1779 [1771]), 81-2. 
untutored Indian and the civilized European have acted upon the same principles' ${ }^{10}$ Yet they ethnocentrically assumed a single trajectory of progress and consigned so-called 'barbarous or savage' contemporary populations to the stalled status of a 'mirrour' reflecting 'the features of our own progenitors'.11

In the 1740s, the French polymath Maupertuis and his compatriot, the naturalist Buffon, brought the paradox of striking physical diversity within a single human species of common ancestry to the forefront of natural history which to that point had normally considered man as an individual. Buffon's landmark essay on 'Varieties in the Human Species' eschews taxonomy in favour of an exhaustive nominalist catalogue of the 'varieties evident between the men of different climates'. ${ }^{12}$ There is as yet no hint of a biological account of the formation of human varieties (races, kinds, or nations) which he attributed to the interaction of three extrinsic causes - climate, diet, and lifestyle. ${ }^{13}$ In 1766 , Buffon proposed an organic explanation for these effects by arguing that 'the influence of the climate' combined with 'the influence of the land' to shape man's 'interior form'. The resultant 'general and constant characters' were perpetuated by reproduction during centuries but Buffon did not doubt that, 'over time', they would be reversible with a return to the original environment. ${ }^{14}$ Still later, he added civility to this causal chain by arguing that, as

${ }^{10}$ J. Millar, Observations Concerning the Distinction of Ranks in Society (London, 1771), iii; the sentence is lacking in the revised and enlarged third edition of Millar's work (1779).

${ }^{11}$ Ferguson, An Essay, 122-3.

${ }^{12}$ G.-L. Leclerc, comte de Buffon, 'Histoire naturelle de l’homme: variétés dans l'espèce humaine', in idem, Histoire naturelle, générale et particulière, 15 vols (Paris 1749-67), vol. 3 (1749), 371-530 (371); P.-L. Moreau de Maupertuis, Vénus physique (s.l., 1745). The Encyclopédie entry on 'Man' puts the established position thus: 'We have followed man from the moment of his conception [sa formation] or his birth [sa vie], to the instant of his death. This is what constitutes the natural history of man' (D. Diderot and d'Alembert, 'Homme', in Encyclopédie, ou dictionnaire raisonné des sciences, des arts et des métiers ..., 28 vols (Paris, 1751-72), vol. 8 (1765), 256-81 (257), original emphasis). See C. Blanckaert, “"Notre immortel naturaliste”: Buffon, la science de l'homme et l'écriture de l'histoire', in Buffon: de l'Homme, edited by M. Duchet (Paris: L’Harmattan, 2006), 407-67 (433-4).

${ }^{13}$ Buffon, 'Histoire naturelle de l'homme', 447-8.

${ }^{14}$ G.-L. Leclerc, comte de Buffon, 'De la dégénération des animaux', in idem, Histoire naturelle, vol. 14 (Paris, 1766), 311-74 (311-16, 321). 
man began 'to civilize himself', he was able to control nature and thereby 'ennoble himself', producing 'abundance' which in turn resulted in a 'large population'. ${ }^{15}$

From the mid-1770s, two separate conceptual innovations promoted race as the collective noun of choice to designate broad subgroups of the human species. In 1777, Buffon differentiated 'the word race in its most extended sense', connoting 'resemblance', from its 'narrowest meaning', synonymous with nation. However, such resemblance was neither innately organic nor permanent since he still insisted that 'the principal varieties depend entirely on the influence of the climate'. ${ }^{16}$ Though theoretically a dead end, this extended signified of race remained popular currency throughout the 19th century. In significant contrast, between 1775 and 1806 two monogenist Germans, the philosopher Kant and the comparative anatomist Blumenbach, married racial taxonomy to the biological conception of a race as ‘unausbleiblich erblich’ ('unfailingly hereditary’). Kant positioned a race taxonomically between a species and a variety while both men classified the single human species into a limited number of distinct races. ${ }^{17}$

The radical new doctrine that physical diversity was innate, permanent, and sharply etched henceforth began to undermine the venerable dogma of human unity. Stimulated by recent developments in comparative anatomy and physiology in an era of political upheaval and renewed colonial competition, the novel signified of race was enthusiastically adopted by French naturalists with the comparative anatomist Cuvier in the van. Cuvier, though professedly monogenist, took racial inequality for granted as a real, immutable product of physical organization: 'There are’, he pronounced, 'intrinsic causes which seem to halt the

${ }^{15}$ Idem, 'Des époques de la nature', in idem, Histoire naturelle, générale et particulière: Supplément, vol. 5 (Paris, 1778), 1-254 (248).

${ }^{16}$ Idem, Histoire naturelle, générale et particulière: Supplément, vol. 4, Servant de suite à l'histoire naturelle de l'homme (Paris, 1777), 462, 555.

${ }^{17}$ J. F. Blumenbach, Handbuch der Naturgeschichte, fifth edition (Göttingen, 1797 [1779]); 23; idem, Beyträge zur Naturgeschichte, second edition, 2 vols (Göttingen, 1806 [1790]), vol. 1, 67-72; I. Kant, 'Von den verschiedenen Racen der Menschen', in Der Philosoph für die Welt, edited by J. J. Engel, 2 vols (Leipzig, 1777 [1775]), vol. 2, 125-64 (125-44, 156-61); idem, 'Bestimmung des Begriffs einer Menschenrace', Berlinische Monatsschrift, 6 (1785), 390-417 (390-409). 
progress of certain races, even under the most favourable circumstances'. ${ }^{18}$ At the turn of the century, the English anatomist White and the French naturalist Virey published the first scientific polygenist treatises on man, prefiguring bitter conflicts over the origins and nature of human diversity which would obsess the science of race for much of the 19th century. ${ }^{19}$

\section{Stadial theory and conjectural history in Oceania}

Emergent racialist terminology and debates between metropolitan savants about human specific unity impinged very little on texts written by European voyagers in Oceania ${ }^{20}$ before the mid-1820s. Conversely, most travellers espoused stadial ideas more or less knowingly. These patterns of textual absence and presence signal, on the one hand, the lag between recent scholarly innovation and its percolation into wider public consciousness; and, on the other, the longevity of 'environmental' factors, especially climate, in conventional understandings of human nature and differences. Oceanic voyagers assumed the reality of a unilinear developmental path that valorized familiar agricultural practices over other modes of life and production and they often failed to recognize or appreciate Indigenous horticulture. So the German naturalist J. R. Forster, who accompanied Cook’s second

${ }^{18} \mathrm{G}$. Cuvier, Le règne animal distribué d'après son organisation, pour servir de base à l'histoire naturelle des animaux et d'introduction à l'anatomie comparée, 4 vols (Paris, 1817), vol. 1, 94. For detailed examination of the late 18th-century paradigm shift in the embryonic science of anthropology from holistic, 'environmental' justification for fluid human varieties to the hierarchical classification of discrete, biologically-determined races, see C. Blanckaert, 'Les conditions d'émergence de la science des races au début du XIX siècle', in L'idée de 'race' dans les sciences humaines et la littérature (XVIII et XIX siècles), edited by S. Moussa (Paris: L’Harmattan, 2003), 133-49; Douglas, 'Climate to crania', passim; G. W. Stocking, Jr., 'French Anthropology in 1800', in Race, Culture and Evolution: Essays in the History of Anthropology (New York: Free Press, 1968), 13-41. ${ }^{19} \mathrm{~J}$.-J. Virey, Histoire naturelle du genre humain, ou recherches sur ses principaux fondemens physiques et moraux [...], 2 vols (Paris, 1800); C. White, An Account of the Regular Gradation in Man [...] (London, 1799). On the bruising but ambiguous conflict between monogenists and polygenists in the 19th-century science of race, see Douglas, 'Climate to crania', 47-70.

${ }^{20}$ In this paper, 'Oceania' is used in the extended sense of the term's early 19th-century French inventors who thus named the 'fifth part of the world' - the great insular zone encompassing what are now maritime Southeast Asia, Australia, Papua New Guinea, Aotearoa-New Zealand, and the Pacific Islands. 
circumnavigation of 1772-1775, insisted in his post-voyage Observations ... on Physical Geography, Natural History, and Ethic Philosophy that the ‘cultivation’ of crops was a prerequisite for 'progress' in 'civilization' and for the attainment of 'improvement and happiness' ${ }^{21}$

A much older developmentalist narrative also recurred in the literature on Oceania: a just-so story, fuelled by local rumour, about the inevitable supplanting of dark-skinned autochthones by more civilized, lighter-skinned immigrants. Early Spanish officials and missionaries in the Philippines reported the presence in the mountains of Luzon of 'natives black in colour' ('naturales negros de color'), with 'wrinkled hair', who were nomadic 'barbarians of little ability', and were assumed to be the earliest inhabitants. ${ }^{22}$ The Spanish navigator Quirós was ‘certain’ that the ‘black-coloured’ people ('de color negro’) he had seen in Santa Cruz (modern Solomon Islands) in 1595 had come originally from the Philippines where 'blacks [negros] said to be the natives of the land' had been driven by invading 'little Moors [los morillos], Visaya Indians, and other castes of people’ to remote places or far-off islands such as New Guinea and the Solomons. ${ }^{23}$

The hoary displacement thesis was resurrected and generalized in the 18th-century, initially by the French littérateur Charles de Brosses as a solution to the Buffonian anomaly

\footnotetext{
${ }^{21}$ J. R. Forster, Observations Made during a Voyage Round the World, on Physical
} Geography, Natural History, and Ethic Philosophy (London, 1778), 373-5, 381. For similar ethnocentric value judgements by voyagers, see J. Cook, The Journals of Captain James Cook on his Voyages of Discovery, edited by J. C. Beaglehole, 4 vols (Cambridge: Hakluyt Society, 1955-74), vol. 1 (1955), The Voyage of the Endeavour 1768-1771, 121, 393, 397; L.-A. de Bougainville, Voyage autour du monde par la frégate du roi la Boudeuse et la flûte l'Etoile en 1766, 1767, 1768 \& 1769 (Paris, 1771), 216; J. A. Bruni d'Entrecasteaux, Voyage de Dentrecasteaux envoyé à la recherche de La Pérouse [...], edited by E.-P.-E. de Rossel, 2 vols (Paris, 1808), vol. 1, 332-4, 354-6; J.-F. de Galaup de La Pérouse, Voyage de la Pérouse autour du monde, publié conformément au décret du 22 avril 1791, edited by L.-A. MiletMureau, 4 vols (Paris, 1797), vol. 2, 206; vol. 3, 186-91.

${ }^{22}$ F. Combes, Historia de las Islas de Mindanao, Iolo, y svs adyacentes: progressos de la religion y armas catolicas (Madrid, 1667), 36; A. de Morga, Sucesos de las Islas Filipinas, edited by F. Perujo (México, D. F.: Fondo de Cultura Económica, 2007 [1609]), 219-20.

${ }^{23}$ P. F. de Quirós, Descubrimiento de las regiones austriales, ed. R. Ferrando Pérez (Madrid: Dastin, 2000), 89, 175. 
that great human diversity had been reported within a single climatic zone in the austral lands. He imagined the legendary 'frizzy-haired blacks' of the Asian islands as 'ancient man in his primitive state of brutish nature'. Purportedly the 'first inhabitants of the torrid zone', they were destroyed by 'foreign colonies of Malay peoples' or driven into 'inaccessible' places or further afield to 'unknown' lands like New Holland. A similar schema, in which an ‘aboriginal black race’ of ‘cannibals’ was ‘subdued’ by ‘more civilized Malay tribes’, was rehearsed by Forster to explain the 'evident difference' between the 'two great varieties' of people, one 'more fair' and the other 'blacker', that he had seen 'living in the same climate' in the South Sea. This was the earliest classification of the Indigenous inhabitants of Oceania though Forster, like Brosses, used race in the ambiguous collective genealogical sense rather than biologically. Both men were monogenist humanists who believed that varieties were 'only accidental' and insisted on a universal potential to 'progress' towards 'civilization'. But both equated darker skin colour with primordiality, lack of civility, and low rank. ${ }^{24}$ By sketching a plausible account of the dispersal or extinction of black autochthonous races, they concretized stadial theory in a particular Oceanic history. This teleological scenario, entangled with later projects of racial taxonomy and Darwinian evolution, was brutally enacted in the 19th- and 20th-century settlement colonies of Australia, New Zealand, and New Caledonia.

\section{Investigating a continent}

I turn now from metropolitan theory to the Oceanic experience of specific voyagers, grounding the history of ideas in the ethnohistory of encounters in order to illustrate reciprocal links or hiatuses between discourse and praxis. Using lexico-semantic analysis, I relate the words applied by voyagers to Indigenous people to the circumstances of their generation, to textual genre, and to author's profession and interests. This strategy at once materializes intellectual history, throws new light on the relationships - crucial for historians - between experience and representation, and suggests novel interpretations of actual encounters between European voyagers and Aboriginal Tasmanians or Australians. My empirical focus is the simultaneous expeditions of Baudin and Flinders, both avowedly

\footnotetext{
${ }^{24}$ C. de Brosses, Histoire des navigations aux terres australes [...], 2 vols (Paris 1756), vol. 2, 347, 376-80; Forster, Observations, 228, 252-335, 353-60.
} 
scientific in intent if nationalist in spirit. The written and visual legacies of these voyages, whether contemporary or reworked, offer rich pickings for ethnohistory because they are thick with what I call 'Indigenous countersigns' - oblique traces of the imprint of local agency on foreign perceptions and representations of encounters. Thus far, such agency has usually been either ignored or taken for granted. ${ }^{25}$

I developed the idea of countersign eclectically from feminist literary critique, from the Gramscian/Subaltern Studies notion of counterhegemonic subaltern subversion of colonial or elite discourses, and from pragmatic appropriation of two key terms in structural linguistics, 'referent' ('thing referred to') and 'signifier' ('expression'). ${ }^{26}$ By denying signifier (signifiant) its strict Saussurean sense of an arbitrary 'image acoustique' ('sound pattern'), paired with a concept or signifié ('signified') to constitute a signe ('sign'), the definition 'expression' allows for the ‘motivated' impression of referents on signifiers. ${ }^{27}$ The referents in this paper include Indigenous behaviour, appearance, and lifestyle - condensed as

${ }^{25}$ B. Douglas, 'Art as Ethno-historical Text: Science, Representation and Indigenous Presence in Eighteenth and Nineteenth Century Oceanic Voyage Literature', in Double Vision: Art Histories and Colonial Histories in the Pacific, edited by N. Thomas and D. Losche (Cambridge: Cambridge University Press, 1999), 65-99; idem, 'In the Event: Indigenous Countersigns and the Ethnohistory of Voyaging', in Oceanic Encounters: Exchange, Desire, Violence, edited by M. Jolly, S. Tcherkézoff, and D. Tryon (Canberra: ANU E Press, 2008), 175-98; idem, 'Encountering Agency: Islanders, European Voyagers, and the Production of Race in Oceania', in Changing Contexts, Shifting Meanings: Transformations of Cultural Traditions in Oceania, edited by Elfriede Hermann (Honolulu: University of Hawai'i Press in association with the Honolulu Academy of Arts, 2011), 74-92. ${ }^{26}$ R. Barthes, 'Le discours de l'histoire', Informations sur les Sciences sociales 6 (1967), 65-75; S. Benstock, Women of the Left Bank: Paris, 1900-1940 (Austin: University of Texas Press, 1986), 349-51; A. Gramsci, Antonio Gramsci: Prison Notebooks, translated and edited by J. A. Buttigieg, 3 vols (New York and Chichester, West Sussex: Columbia University Press, 1996 [1975]), vol. 2, 21; R. Guha, 'The Prose of Counter-Insurgency’, Subaltern Studies 2 (1983), 1-42. I fully explicate the theory of countersign in my forthcoming monograph Savants, Voyagers, and Encounters in Oceania 1511-1840, under contract with Palgrave Macmillan for publication in 2013.

${ }^{27}$ F. de Saussure, Course in General Linguistics, translated and edited by R. Harris (Peru, IL: Open Court Publishing, 1986 [1972]), 66, 130-1; idem, Cours de linguistique générale: Edition critique, edited by R. Engler, 2 vols (Wiesbaden: Otto Harrassowitz, 1989 [1968]), vol. 1, 149-51. 
'agency'. Filtered through the perceptions, presuppositions, and emotions of foreign observers, referents can impinge on some of the signifiers used to represent them. They do so directly as consciously processed signs and inadvertently as countersigns. Countersigns are variously manifest in written and visual texts: in choice and disposition of words and motifs; in tense, mood, and voice; in tone and style; and in presence, absence, emphasis, ambiguity, tension, and contradiction.

In July 1802, Flinders set out from the English penal settlement at Port Jackson to circumnavigate the continent on H. M. S. Investigator (Figure 1). He was joined by a 'native friend’ from Broken Bay, the 'worthy and brave’ Bungaree (Figure 2) who, during an earlier voyage Flinders made to Moreton Bay, had greatly facilitated 'friendly intercourse' with the local inhabitants. ${ }^{28}$ Accounts of the circumnavigation are strewn with signs and countersigns of Bungaree's activity - particularly those produced by Flinders himself and the botanist Robert Brown who benefited most from Bungaree’s contributions, since he was often a key figure in encounters. At Sandy Cape, 'our native’ Bungaree took the lead in communicating with a reluctant group of men. Having 'stripped off his clothes and laid aside his spear', he 'boldly' approached them, 'singly, unarmed, and naked'. They eventually allowed him to join them, followed by the Europeans, and were given presents, a meal of porpoise blubber, and a lesson from Bungaree in using a woomera or spear thrower with which they were unfamiliar. Flinders's journal makes it clear that Bungaree was the crucial 'medium' for achieving this ‘mild \& sociable’ demeanour. Brown signified the agency involved in equally explicit terms: 'This intercourse was brought about by Bongare'. ${ }^{29}$

\footnotetext{
${ }^{28}$ M. Flinders, A Voyage to Terra Australis: [...] Prosecuted in the Years 1801, 1802, and 1803 in His Majesty's Ship the Investigator [...], 2 vols (London, 1814), vol. 1, 235; vol. 2, 10.

${ }^{29}$ R. Brown, Nature's Investigator: the Diary of Robert Brown in Australia, 1801-1805, edited by T. G. Vallance, D. T. Moore, and E. W. Groves (Canberra: Australian Biological Resources Study, 2001), 231-2; M. Flinders, 'Journal of Proceedings on Board the Investigator, 25 January 1801-10 June 1803’, 2 vols, manuscript (Sydney: State Library of New South Wales, James Fairfax Matthew Flinders Electronic Archive, online http://acms.sl.nsw.gov.au/item/itemdetailpaged.aspx?itemid=153830, accessed 12 February
} 2011), vol. 2, images 25-6; idem, Voyage, vol. 2, 10-11; P. Good, The Journal of Peter Good: Gardener on Matthew Flinders [sic] Voyage to Terra Australis 1801-03, edited by P. I. 


\section{Insert Figures 1 \& 2}

In late January 1803, the Investigator spent several days at Blue Mud Bay in northeast Arnhem Land, country then and now occupied by Yolngu people. This visit was the occasion of the voyage's only lethal clash which left ample textual traces of the strong and conflicting emotions evoked. All parties were evidently moved by unstable blends of caution, fear, curiosity, and desire, culminating in misunderstanding and deadly violence. On 21 January, Flinders sent a party to cut wood on a small island in the middle of the bay. Everyone who went ashore was 'tolerably well armed' because recent 'footprints' had been seen and 'we expected to meet with Indians'. Shortly afterwards, six local men armed with spears arrived at the island by canoe. According to the journal of a seaman, Samuel Smith, they were 'Observ'd to creap along', 'as if their Intention was to come suddingly on the Party'. Approached from various directions by sailors and ‘scientific gentlemen' who were nervous but eager for a 'friendly interview', they evidently feared 'to be surrounded' and 'scamperd off', though Brown thought they looked back 'apparently with some curiosity'. Later, the master's mate in charge of the wooding party, carrying a loaded musket, tried again to establish contact with them but was stabbed in the chest when he sought to take a proffered spear. He managed to get away and was taken to the ship with several non-fatal wounds. ${ }^{30}$

One, certainly, and probably two of the assailants were less fortunate. They were pursued by boat and on foot and in the heat of the moment the sailors' excitement and lust for vengeance triumphed over Flinders’s orders for restraint. When three men were seen 'Making their Escape' in the canoe, they were at once fired on with 'Muskets loaded with ball \& Buck Shot'. Brown, who deplored violence, alleged that the sailors 'even went up to the middle in water to get nearer the poor wretches'. Two men jumped overboard but the third was shot dead in the canoe and his body afterwards sank. The next morning, a corpse was found on the

Edwards, Bulletin of the British Museum (Natural History): Historical Series 9 (London: British Museum (Natural History), 1981), 82-3. Three months later, on the western side of Cape York Peninsula, Bungaree again went ashore 'naked and unarmed' towards a party of men armed with spears but they 'retreated' and refused all communication (Flinders, Voyage, vol. 2, 126).

${ }^{30}$ Brown, Nature's Investigator, 345-7; Flinders, 'Journal', vol. 2, images 350-2; idem, Voyage, vol. 2, 195-7; Good, Journal, 111-12; S. Smith, Sailing with Flinders: the Journal of Seaman Samuel Smith, edited by P. Monteath (North Adelaide: Corkwood Press, [2002]), 57. 
beach. Flinders deduced that it was not the man killed in the canoe but one of his companions since the body was found 'in the posture of a man who was just able to crawl out of the water and die'. He ordered the retrieval of the body, 'the painter being desirous of it to make a drawing, and the naturalist and surgeon for anatomical purposes'. Brown’s assistant, the gardener Peter Good, described the man’s appearance, decorations, and dress: he was 'under the usual size' but resembled 'the generality of the Natives of New Holland—a long beard, high forehead, thick lips Nose short thick \& turned up'; he wore 'many bracelets on his arms \& a band round his middle on which was fastened a piece of bark to cover his privates’. Smith noted that he had been 'shot through the Back' and that 'the Surgeon Cut off his Head \& took out his Heart \& put them in Spirits'. The artist William Westall produced a moving but confronting sketch of an apparently partly dismembered body - though the separated foot was probably artistic licence dictated by the size of the page (Figure 3 ). ${ }^{31}$

\section{Insert Figure 3}

This episode has enduring emotional valence. In a speech delivered in Darwin in 2003, the Yolngu leader and musician Mandawuy Yunupingu made it emblematic of when 'my people had first met science'. While acknowledging that 'fear and confusion played a large part in the murder', he was less charitable about the aftermath: 'Every time I hear the story the bit that I find hardest to listen to comes right at the end. It is that part where they dissected and sketched one of the bodies. And the[n] cut off the head to put it in a bottle of alcohol'.$^{32}$ This troubled legacy is complicated by a gruesome irony stemming from a marine’s coincident death from sunstroke. Whereas the anonymous body of 'the native' was mutilated and its parts retained as disembodied specimens, the marine was memorialized by

${ }^{31}$ Brown, Nature’s Investigator, 346; Flinders, 'Journal', vol. 2, images 352-4; idem, Voyage, vol. 2, 195-7; Good, Journal, 112; Smith, Sailing with Flinders, 57-8; W. Westall, [Blue Mud Bay, Body of a Native Shot on Morgan's Island], pencil drawing, in idem, [Drawings, 18011803] (Canberra: National Library of Australia, PIC R4256-R4394 LOC Westall boxes 1-14, online http://nla.gov.au/nla.pic-an4565197, accessed 14 February 2011), box 11.

${ }^{32}$ M. Yunupingu, 'Bringing our Pasts into our Futures', transcript of speech at Charles Darwin University (Darwin: Charles Darwin University, 2003, online www.cdu.edu.au/cdss2003/presentations/mandawuy_yunupingu.pdf, accessed 12 February 2011), [2]. 
Flinders in the toponym 'Morgan's Island'. There was further asymmetry in the disposal of the two corpses which Smith alone recorded: 'This Day we Interr'd Morgan according to the Usual serimony perform'd at sea, afterwards the Native was hove overboard \& seen to be devour'd by Sharks'.33

Flinders’s disquiet and ambivalence about the affair are patent in his writings. In retrospect in his published narrative, he conjectured that 'our people must have been the aggressors' and condemned the master, who had led the punitive parties, 'for having acted so contrary to my orders'. However, in the more immediate context of his shipboard journal, Flinders was more equivocal and censured the master by implication only. He thought that the unusual boldness of the local men's actions and the absence of women or children seemed 'to indicate an attack premeditated on their part' and that, on balance, 'the natives will not have suffered more than their violence merited'. His post-mortem insensitivity was no doubt largely pragmatic: 'the mischief being unfortunately done', why not satisfy the desire of the scientific gentlemen for human specimens? why not concurrently meet the crew's symbolic needs to combat death with ritual and to avenge insults inflicted by despised but frightening savages? Nonetheless, the brutal contrast in the captain's authorized treatment of the bodies surely also indexed his unequal estimation of the humanity of an unknown native relative to even a lowly member of his own crew. ${ }^{34}$

Bungaree is not mentioned in accounts of the Investigator's stay at Blue Mud Bay. But he loomed large in a series of ambiguous encounters at nearby Caledon Bay in which the Europeans were repeatedly forced to react to the desires and initiatives of local Yolngu people who were 'almost certainly' relatives of the man killed at Blue Mud Bay. ${ }^{35}$ Brown again represented Bungaree as the 'means' by which the initial landing party 'came to a friendly interview with the natives'. When Flinders and the botanists went ashore, a dozen men ran to meet them and 'expressed much joy, especially at seeing Bongaree'. Ten

\footnotetext{
${ }^{33}$ Flinders, 'Journal', vol. 2, images 351, 353; idem, Voyage, vol. 2, 197, 198, original emphasis; Smith, Sailing with Flinders, 58.

${ }^{34}$ Flinders, 'Journal', vol. 2, images 353-4; idem, Voyage, vol. 2, 196, 197.

${ }^{35}$ H. Morphy, 'Encountering Aborigines', in The Encounter, 1802: Art of the Flinders and Baudin Voyages, edited by S. Thomas (Adelaide: Art Gallery of South Australia, 2002), 148-63 (158).
} 
accompanied Brown's party on an excursion inland, 'unarm'd' and 'in perfectly good understanding'. Yet during the walk, two men stole a hatchet and a musket which was later returned, broken. The next day, an axe was stolen and Flinders ordered a hostage to be held against its return. A youth called 'Woga' was duly seized and kept captive for two days. ${ }^{36}$ Westall's portrait of 'Woogah' (Figure 4) suggests the 'anxiety' and the 'melancholy' noted by several observers. ${ }^{37}$ In general, though, he was 'tolerable cheerful' while on board the ship. On the first evening, Woga's compatriots brought a girl to the beach 'who by expressive signs they offered to Bongaree' and indicated that 'he might have her if he would land'. In his narrative, Flinders opined that they sought to ‘entice’ Bungaree ashore with the aim of 'seizing him by way of retaliation' but no such surmise was recorded at the time. The following morning, Woga applied 'earnistly' to him to be taken ashore and he tried 'to prevail on Bungery to go with him' when freed that evening. ${ }^{38}$ This catalogue of baffling actions encodes enigmatic countersigns of Indigenous understandings - their assumptions, perhaps, that controlling authority was vested in Bungaree or that he was a surrogate for their dead kinsman.

\section{Insert Figure 4}

Flinders's decision to liberate Woga with the axe unrestored is also a countersign - of both local agency and the resultant vulnerability of sailors in uncharted waters amid independent, bellicose populations. After taking his hostage, Flinders had felt obliged to protect the shore camp with the ships' guns since the inhabitants now 'came armd' and 'with stones apparently intending to attempt a rescue'. Caledon Bay was not a comfortable haven for the English. A 'not very prudent' attempt to botanize by Brown and his party ended in a nervous retreat to the beach where buckshot was fired at a dozen well-armed men, wounding two. Henceforth, the 'gentlemen did not think it safe to proceed in their business' and they

\footnotetext{
${ }^{36}$ Brown, Nature’s Investigator, 352, 354, 355; Flinders, 'Journal', vol. 2, images 371-2, 374-7; idem, Voyage, vol. 2, 205-10; Good, Journal, 114-15.

${ }^{37}$ Good, Journal, 115; Flinders, Voyage, vol. 2, 210; W. Westall, 'Woogah. Caledon Bay', pencil drawing, in idem, [Drawings] (online http://nla.gov.au/nla.pic-an4564868, accessed 14 February 2011), box 11.

${ }^{38}$ Flinders, 'Journal', vol. 2, images 375-6, 382; idem, Voyage, vol. 2, 208-10, 214; Good, Journal, 115-16.
} 
complained that 'during our Stay here we had been so much disturbed with the Natives that we could not examine the Country as we could have wished'. Flinders reflected ruefully that, far from achieving the intended intimidation and restitution, Woga's detention had 'caused some annoyance to us, and mischief to his countrymen'. About to depart and fearing they would 'do injury to others who might come after us', Flinders released the boy with 'some clothing and presents'. The English saw no more of him or 'these Arnhems'. ${ }^{39}$

\section{Naturalizing an island}

In the meantime, the only protracted French encounters with Indigenous people during Baudin's two-year sojourn in the seas around New Holland had taken place in Van Diemen's Land in early 1802. The voyage is well known from the official narrative written mainly by the naturalist François Péron, a professional protégé of Cuvier and an enemy of Baudin. Péron’s mostly very negative representations of Aboriginal Tasmanians and Australians are quite notorious. ${ }^{40}$ As the historian of anthropology George W. Stocking, Jr., argued in the 1960s, Péron’s narrative embodies the intellectual shift from the nostalgic primitivism and critique of civilization common in late Enlightenment France to the harsh, often racialist progressivism of the new century. ${ }^{41}$ But the work is also an intimate story of one man's

\footnotetext{
${ }^{39}$ Brown, Nature’s Investigator, 360, 361; Flinders, 'Journal', vol. 2, images 374, 376; idem, Voyage, vol. 2, 209-10; Good, Journal, 116.

${ }^{40}$ See, for example, S. Anderson, 'French Anthropology in Australia, the First Fieldwork Report: François Péron's “Maria Island: Anthropological Observations”', Aboriginal History 25 (2001), 228-42; J. Copans and J. Jamin (eds.), 'Présentation: de la filiation déviée à l’oubli des origines', in Aux origines de l'anthropologie française: les mèmoires de la Société des observateurs de l'homme en l'an VII, edited by J. Copans and J. Jamin (Paris: Le Sycomore, 1978), 23-67; M. J. Hughes, 'Tall Tales or True Stories? Baudin, Péron, and the Tasmanians, 1802', in Nature in its Greatest Extent: Western Science in the Pacific, edited by R. MacLeod and P.F. Rehbock (Honolulu: University of Hawaii Press), 65-86; Rhys Jones, 'Philosophical Time Travellers', Antiquity 66 (1992), 753-4; S. Konishi, 'François Péron and the Tasmanians: an Unrequited Romance', in Transgressions: Critical Australian Indigenous Histories, edited by I. Macfarlane and M. Hannah (Canberra: ANU E Press, 2007), 1-18. ${ }^{41}$ Stocking, 'French Anthropology', 31-41.
} 
experience of this transition, provoked by encounters in Van Diemen's Land. ${ }^{42}$ In the event, Péron's residual primitivism evaporated in the face of what he called the 'cowardly and ferocious treachery [perfidie]' of 'l'homme de la nature' ('the man of nature') - in other words, their incomprehensible agency. ${ }^{43}$ I consider Péron's prose in the next section but at this point outline the key encounters from Baudin's contemporary mariner's viewpoint rather than the dramatic stratagems of the naturalist's retrospective narrative.

Baudin's shipboard journal gives a dispassionate empirical account of a succession of wary, sometimes tense, but mostly amicable French meetings with small groups of people at Bruny Island (Nuenonne band) and Maria Island (Tyreddeme band) between 14 January and 27 February (Figure 5). ${ }^{44}$ Baudin was personally involved in five encounters, the first with three men who approached his small party 'without the least distrust [méfiance]', were embraced by them, and were given 'a few trifles [bagatelles]'. The next day, a fishing party intermingled with a large number of local men, women, and children, mutually trusting 'as if without fear'. They were 'heaped [comblés] with presents' but this gratifying scene culminated in an 'unexpected accident' as the French were about to board their boat, when someone hurled a single spear which deeply wounded a midshipman in the neck. ${ }^{45} \mathrm{~A}$ fortnight later, Baudin and the artist Nicolas-Martin Petit were among a small group of

${ }^{42}$ F. Péron and L. de Saulces de Freycinet, Voyage de découvertes aux terres australes [...] sur les corvettes le Géographe, le Naturaliste, et la goëlette le Casuarina, pendant les années 1800, 1801, 1802, 1803 et 1804. Historique, 2 vols (Paris, 1807-16), vol. 1 (1807), 218-302. ${ }^{43}$ Ibid., 236, 471, original emphasis.

${ }^{44}$ N. Baudin, 'Journal du 4 thermidor an 9 au 8 ventose an 10', in idem, 'Journal du Cap ${ }^{\text {ne }}$ de vaisseau $\mathrm{N}^{\mathrm{s}}$. Baudin Commandant en chef les corvettes Le Geographe \& le Naturaliste destinées par ordre du Gouvernement à un voyage de decouvertes', 5 vols, manuscript (Paris: Archives nationales, 1800-3, 5 JJ 36-40), vol. 3 (1801-2, 5 JJ 38), 203-60. This journal remains unpublished in French but there is a sound English translation - N. Baudin, The Journal of Post Captain Nicolas Baudin Commander-in-Chief of the Corvettes Géographe and Naturaliste [...], translated by C. Cornell (Adelaide: Libraries Board of South Australia, 1974). However, I refer to Baudin's original journal and cite my own translations because of the need for lexical and semantic precision. For a detailed reconstruction of the names and territories of Indigenous groups in Tasmania during the early contact period, see L. Ryan, The Aboriginal Tasmanians (Crows Nest, NSW: Allen \& Unwin, 1996 [1981]), 12-44.

${ }^{45}$ Baudin, 'Journal’, 205-10. 
Frenchmen who spent several hours with three men who initially ordered them to go back to their boat but eventually joined them when both sides put down their weapons. Baudin had already noted their extreme fear of firearms. The men closely examined their visitors' possessions, clothes, and bodies and exchanged spears for uniform buttons which they much admired. Yet, once again, a seemingly friendly meeting ended violently as the Europeans were returning to the boats. One man snatched a portrait Petit had drawn; Petit grabbed it back without resistance; another threatened Petit with a log; and they began to hurl stones at the French, wounding Baudin 'slightly' ('légèrement') on the hip. He put his assailant to flight by merely aiming his weapon. ${ }^{46}$ Baudin's remaining encounters were cheerful and friendly, including one with the earlier stonethrowers who seemed neither nervous nor abashed. He concluded that 'either their character is not wicked [méchant] or they judge us incapable of doing them harm'. ${ }^{47}$

\section{Insert Figure 5}

Baudin's journal is consistently evenhanded and pragmatic in tenor, even when reporting the twin contretemps. At this point, he presumed rational, if unknown motives for the attacks and did not condemn the assailants. His representations of people are largely favourable, if indirectly racialized by traces of aversion to Africans and to blackness. The persons Baudin saw at Bruny Island - one is depicted in an engraving of Petit's portrait (Figure 6) - had 'nothing unpleasant [désagréable]' about their looks; their features had ‘character’; their hair was 'frizzy’ ('crépu’) but much less ‘thick’ than African hair; their noses 'in no way' resembled that of the Negroes of Africa; their skin colour, was 'much

${ }^{46}$ Ibid., 209, 226-9. Some details of this encounter are taken from the journal of the Naturaliste's commander, Hamelin, who was also present and who remarked: 'The fear inspired by guns in this small tribe [peuplade] is such that I would rather be alone in their forests with a gun to defend myself against them than to find myself one of four without guns’ (J. F. E. Hamelin, '[Journal de] Jaques Félix Emmanuel Hamelin des Essarts cap. ${ }^{\text {tne }}$ du frégate comm. ${ }^{\mathrm{t}}$ le Naturaliste, corvette destinée avec celle le Géographe, sous les ordres du cap. $^{\text {tne }}$ de v. ${ }^{\text {au }}$ Baudin, p. ${ }^{\mathrm{r}}$ une exp. ${ }^{\text {don }}$ de découverte, armée et equippée p. ${ }^{\mathrm{r}} 4$ ans', 2 vols, manuscript (Paris: Archives nationales, 1800-3, 5 JJ 41-2), vol. 2, 86-8, 94).

${ }^{47}$ Baudin 'Journal', 230-1, 246-9, 256-7. 
closer to that of the Caribs of America than to the Africans of the Guinea coast'; and they were 'gentle and peaceable'. ${ }^{48}$

\section{Insert Figure 6}

Months later, Baudin wrote a long report to the Navy Ministry with an ethnographic section 'On the natives we found in the [D’Entrecasteaux] Channel and their conduct towards us', plus another page 'On the natives' of Maria Island. ${ }^{49}$ In sharp contrast to the existential restraint of the descriptive passages in his journal, Baudin in hindsight indignantly denounced earlier voyagers for representing these people as 'good' and 'peaceable' ('paisible'), thereby setting an unreliable precedent. Writing for a demanding, perhaps carping official audience, he exaggerated the difficulties he had faced, including the violence encountered at Bruny Island - the single spear of the journal became 'several' while his own injury was inflicted 'quite forcefully [vigoureusement]' by one of a 'hail of stones' ${ }^{50}$ He made the two assaults emblematic of the ingratitude and 'fickleness' ('l'inconstance') of 'primitive men of nature', at the 'furthest possible degree of civilization', who had been 'heaped' with gifts and given 'no provocation' to attack. Bemused by their inexplicable mood shifts back and forth from amity to hostility and unable to form a clear idea of their 'character', Baudin now ascribed

\footnotetext{
${ }^{48}$ Ibid., 206, 227, 253-4.
}

49 'Des naturels que nous trouvâmes dans le Canal et de leur conduite envers nous' and 'Des naturels [de l'île Maria]', in N. Baudin, 'Le commandant en chef l'expédition de découvertes au Ministre de la Marine et des Colonies à Paris. [...] Port Jackson Nouvelle Hollande le 20 brumaire an 11 de la République française [11 November 1802]', unpaginated manuscript (Vincennes, France: Service historique de la Défense, Archives centrales de la Marine, 1802, $\mathrm{BB}^{4}$ 995). These ethnographic sections of Baudin's report were published in English translation in N. J. B. Plomley, The Baudin Expedition and the Tasmanian Aborigines 1802 (Hobart, TAS: Blubber Head Press, 1983), 104-9; and a French version from a copy of the report sent to the Muséum national d'Histoire naturelle was published as N. Baudin, 'Des naturels que nous trouvions et de leur conduite envers nous', in Copans and Jamin (eds.), Aux origines de l'anthropologie française, 207-17.

${ }^{50}$ Baudin had made an initial move towards this revaluation in the ethnographic summary in his journal where, on reflection, he reconfigured the second incident as an attack on the French with 'a hail of stones, thrown very adroitly and even from very far away', one of which wounded him 'quite deeply [fortement]' (Baudin, 'Journal', 256). 
the brazen reappearance of the unarmed stonethrowers to 'faulty memory' - to defective minds rather than his earlier implication of moral innocence or strategic choice.

In language and tone, the prose of this section of the report seesaws between empirical description and emotional outburst, the oscillation itself a countersign of Indigenous agency. So too is Baudin's candour about the insecurity of sailors on little-known shores, dependent for vital supplies on the 'good understanding [bonne intelligence]' established with local people. 'Experience', he remarked, had taught him that 'superior force' was not always the only guarantee against 'the traps of the man of nature' and that 'prudence' could avert endless alarms about the safety of crew members working ashore. Though the subsequent conduct of the Bruny Islanders avowedly caused the French 'only slight annoyance [légers mécontentements]', those fleeting episodes of minor aggression infused the text with uncertainty and inspired the cautionary moral that later voyagers 'must not drop their guard' in dealings with these people because 'too much confidence could be just as dangerous as ‘too much severity’. Nagging frustration with their volatility paralleled a retrospective shift in the tone of Baudin's physical description, from the positive spirit of the journal to marked ambivalence, while still rejecting any African analogy: they were of 'below average [médiocre]' height and 'quite poorly built'; their nose was 'slightly squashed' but less so than 'that of the Africans'; 'their look, without being wild', was 'in no way agreeable, although lively and animated'. ${ }^{51}$

Notwithstanding the harsher tone of Baudin's report, his strictures therein against 'the man of nature' he encountered at Bruny Island voiced a practical navigator's inductive griefs at the human 'fickleness' which complicated his own tasks and endangered his crews. In contrast, Péron idealized, capitalized, and italicized 'I'Homme de la Nature', 'so close to the zero point of civilization', as an a priori construct in a philosophical polemic who failed to meet the test of Péron’s own experience. ${ }^{52}$ The prevailing emotion expressed in Baudin’s

\footnotetext{
${ }^{51}$ Baudin, 'Des naturels que nous trouvâmes'.

${ }^{52}$ Ibid.; F. Péron, 'T̂le Maria: observations anthropologiques: entrevue avec les naturels de cette île et description d'un tombeau trouvé sur la côte nord de la Baie de l'Est. Ventose an $\mathrm{X}^{\mathrm{e}}$ [February 1802]', manuscript, in Collection Lesueur, 'Expédition aux Terres Australes (1800-1804)' (Le Havre, France: Muséum d’Histoire naturelle, dossier 18, item 18040), 1-2, original emphasis.
} 
report is irritation whereas much of Péron's writing on Van Diemen's Land is suffused with trepidation and abhorrence. The common denominator is inscrutable Indigenous behaviour.

\section{Words for people and the science of race}

The language used in Péron's published narrative of 1807 to describe or refer to Indigenous people differs remarkably from that of every other text produced by these two voyages. The contemporary accounts, including Péron’s, mostly apply a neutral or only mildly demeaning palette of words to people encountered. The aggregate noun people and the general plurals inhabitants, men, and persons are scattered through all these texts but by far the most common plurals are natives and its French cognate naturels. In ancient English usage, native meant 'a person born in bondage'. By the 17th century, native and naturel had acquired their modern senses of 'A person born in a specified place, region, or country' or an 'original inhabitant of a country' and their often disparaging plural application to Indigenous people. In both languages, native was applied in 'joking' ('par plaisanterie') or 'mildly depreciative' fashion to local or provincial populations within 'civilized nations' ${ }^{53}$ Flinders consistently used natives in his Investigator journal but his published narrative of 1814, alone amongst all these texts, often supplements generic plurals with 'Indians' and the occasional 'Australians'.54

The word savage figures rarely in the contemporary accounts. I found only one adjectival usage by Baudin while his colleagues occasionally made the noun sauvage a synonym for naturel. Of a handful of English examples, one is an Indigenous countersign imbued with visceral emotion. The seaman Smith consistently referred to local people as 'Natives' but the assault on his shipmate at Blue Mud Bay provoked a lexical shift from

${ }^{53}$ Le dictionnaire de l'Académie françoise, dedié au roy, 2 vols (Paris, 1694), vol. 2, 109; S. Johnson, A Dictionary of the English Language [...], 2 vols (London, 1756), vol. 2; E. Littré, Dictionnaire de la langue française, 4 vols (Paris, 1873-4), vol. 3, 696; Oxford English Dictionary, third edition (Oxford: Oxford University Press, 2012, online http://www.oed.com/view/Entry/125303, accessed 21 March 2011).

\footnotetext{
${ }^{54}$ Flinders, Voyage, vol. 1, 146; vol. 2, 138, 205, 212, 345. Apparently deterred from
} applying his preferred name of 'Australia' to the continent by Banks's weighty objections, Flinders nevertheless slipped the term into his 'General Chart of Terra Australis or Australia' (Figure 1) and by extension into his human nomenclature. 
'Natives' to 'Savage': 'Aproaching them in order to be Friendly with them, one of the Natives pressented A spear to Mr Whitewood. On holding out his Hand to receive the pressent, the Savage thrust it into his breast'. ${ }^{55}$

Collective nouns for human groupings are also remarkably sparse in these texts. They are virtually absent from first-hand descriptions of encounters since travellers evidently met persons, not tribes or nations or races. They are only slightly more common in ethnographic passages though collective terminology is normative in this mode. Writing ethnographically in both journal and report, Baudin referred fleetingly to the inhabitants of Van Diemen's Land as 'these peoples' and as 'a small tribe [peuplade]'. ${ }^{56}$ Two collective nouns also feature in the 'general remarks' on Caledon Bay in Flinders's journal - the sole such instances - and are rehearsed in his narrative: 'The natives of this bay are doubtless of the same race as those of Port Jackson and King Georges Sound. In personal appearance they are somewhat behind some tribes that we have seen, but the difference is not considerable'. However, he was clearly using race casually, with the ambiguous connotation of 'common origin', rather than in its embryonic biological sense. ${ }^{57}$

Flinders's occasional ethnological musings compare the relative 'superiority' in appearance, material culture, or degree of (civil) society attained by different groups but the stadial logic in such passages is always environmental rather than racial. The inconsiderable physical 'difference' of the Caledon Bay people was due to 'a less abundant supply of food'. The people he had seen at Moreton Bay lived 'more in society' and were 'much better lodged' that those further south because they fished with 'large nets' which ensured a 'more certain' food supply, required 'co-operation', and were not very portable; the 'use of nets' in turn 'arose from the form of the bay'. ${ }^{58}$ A subtext of this passage is that the Indigenous people of New Holland were capable of inventiveness and improvement in suitable settings.

\footnotetext{
${ }^{55}$ Smith, Sailing with Flinders, 57.

${ }^{56}$ Baudin, 'Journal', 254; idem, 'Des naturels que nous trouvâmes'.

${ }^{57}$ Flinders, 'Journal', vol. 2, image 381, my emphasis; idem, Voyage, vol. 2, 212.

${ }^{58}$ M. Flinders in D. Collins, An Account of the English Colony in New South Wales, from its First Settlement, in January 1788, to August 1801 [...], 2 vols (London, 1802), vol. 2, 253-5; Flinders, 'Introduction: Prior Discoveries in Terra Australia', in idem, Voyage, vol. 1, i-cciv (cxcviii); idem, Voyage, vol. 2, 212.
} 
In marked contrast to these sporadic nominalist usages, Péron’s narrative of 1807 is pervaded by collective nouns - a clear symptom of essentialism. This should not surprise since his aims in the published work were abstract and anthropological as well as empirical and historical. Such nouns include peuple (usually in the plural), peuplade, tribu ('tribe'), nation, and race. Moreover, race acquires taxonomic and biological implications in the course of the actual narrative. A young man called Bara-Ourou - described as both 'the most handsome man' and 'the most relentless' adversary ('le plus acharné contre moi’) encountered by Péron at Maria Island where Petit drew his portrait (Figure 7) - had 'spindly, weak extremities', a so-called 'structural flaw [vice de conformation] common to his whole race'. ${ }^{59}$ This essentialist presumption that a widespread physical trait constituted a 'decided' racial character is at odds with Flinders's empirical relativism on the matter. In 1802, in the Gulf of Carpentaria, he met the two 'tallest Indians' he had ever seen and explained that, 'like most of the Australians, their legs did not bear the European proportion to the size of their heads and bodies'. However, their shorter companion was, 'according to our notions, better proportioned'. ${ }^{60}$

\section{Insert Figure 7}

Since the 'general' flaw of thin limbs was also shared by the 'race of men' inhabiting New Holland, Péron at this point made it the keystone of his argument for the general physical superiority of ‘civilized’ over 'savage man'. The flaw, he contended, was most likely a product of their 'social state' - the 'wretchedness and habitual famine' in which they lived which in turn resulted from ‘the savage state’ itself. Rehearsing mature Buffonian logic, he outlined an optimistic developmental scenario whereby 'progress in civilization', by ensuring 'abundance', would promote physical strength, eradicate the flaw, and guarantee population increase. ${ }^{61}$

Péron’s claim to have ‘proved’ empirically the physical superiority endowed by civilization rested on a series of experiments conducted with a dynamometer to test the relative bodily strength of selected inhabitants of Van Diemen's Land, New Holland, and

\footnotetext{
${ }^{59}$ Péron and Freycinet, Voyage, vol. 1, 280, 287.

${ }^{60}$ Flinders, Voyage, vol. 2, 137, my emphasis; Péron and Freycinet, Voyage, vol. 1, 465.

${ }^{61}$ Ibid., 446, 448, 450, 465-71.
} 
Timor against that of 17 members of the French expedition and 14 Englishmen from Port Jackson. Notwithstanding the highly dubious conception and execution of these tests, he calibrated their results into a 'gradation of the social state' which doubles as a global racial classification. Péron’s social sequence consigns the 'race’ occupying Van Diemen’s Land to the 'last degree' as the 'most savage of all', by virtue of the 'truly extraordinary lack of strength [vigueur]' shown in his tests by 12 suspicious, sometimes uncooperative men. The ‘race’ occupying New Holland ranks only slightly higher because it was 'scarcely more civilized' and the 17 men tested were seemingly only a little stronger. The next three 'degrees' are assigned in principle to the New Guineans, the New Zealanders, and the Pacific Islanders whom Péron had neither seen nor tested. The sixth 'rung' ('échelon') is allotted to the 'Malay peoples' of Timor and nearby islands on the basis of tests conducted on 56 men, three of them Chinese. He found that, despite a 'quite advanced state of civilization', the Malay 'race’ was 'much weaker' and still ‘incomparably less civilized’ than the English and the French and therefore ranked much lower. He concluded ambiguously that the physical strength of the various 'peoples' of the globe was intimately linked, on the one hand, to 'the details of their physical constitution, their social organization', and on the other hand, to 'the history of the climate, its temperature, its diverse productions, etc.' ${ }^{62}$ He thereby hedged on the key contemporary question of the relative significance of external conditions or internal somatic qualities in the generation of human variation.

At this point in the text, Péron’s ideological agenda - his panegyric for civilization required a social explanation. But at a later stage, in a chapter relating aspects of antipodean zoology to the 'physical history' of the human species, he made an overtly biological argument for the 'absolute difference' between the 'races’ peopling Van Diemen’s Land and New Holland. They had, he insisted, 'almost nothing in common', thin limbs apart, neither in their customs, 'crude arts' ('leurs arts grossiers'), material culture, and language, nor in their ‘entire physical constitution'. This total ‘dissimilarity’ was ‘even’ manifest in 'a character that everyone agrees is the most important differentia of the diverse races of the human species': the 'nature of the hair' ${ }^{63}$ A footnote asserts that the Van Diemen's Landers 'differ

\footnotetext{
${ }^{62}$ Ibid., 452-84.

${ }^{63}$ Ibid., vol. 2, 161, 163-4.
} 
essentially from all other known peoples' ${ }^{64}$ The phrase arguably implies separate autochthonous origin, a radical but by no means unthinkable concept by this time, given the recent publication of White's and Virey's polygenist treatises. ${ }^{65}$

Péron's congealing racialism is evident in relation to Timor where he spent four months and identified 'three absolutely distinct races of men'. The 'first' comprised 'the natives’ who had been 'pushed back into the interior', lacked 'almost every social institution', lived entirely by hunting and gathering, were 'fierce' and warlike, reputed to be 'cannibals', and combined all the physical attributes of the 'true Negro race' ('la race nègre, proprement dite') - 'short, woolly, frizzy hair', 'black colour, etc' ${ }^{66}$ The second - at once romanticized and patronized - were 'reddish copper-coloured' Malays with 'long hair', descendants of the archipelago’s ancient conquerors who retained their ancestors’ independence, pride, and daring. Beside the Malays, though unable to dominate them, were the Chinese who were 'clever traders' but 'cowardly and weak' ${ }^{67}$ Entangled in Péron’s confident racial taxonomy of Timor were old tales and stereotypes about remnant Indigenous Negro populations supposedly banished to the interior of the larger Asian islands, as evoked in Brosses and Forster's conjectural histories. Unsurprisingly, most of Péron’s reported interlocutors were 'Malay'.

Péron's narrative is permeated by exaggerated rhetoric and negative epithets. The term sauvages as a plural noun and adjective - especially in the reiterated phrases 'peuples sauvages' and 'hordes sauvages' - figures nearly twice as often as naturels while the two nouns are no longer always simple synomyms. Like the seaman Smith's fleeting recourse to 'Savage', Péron’s term sauvages is often inflected with particular venom and as such is an Indigenous countersign: in his syntactical juxtaposition of the phrases 'cowardly and ferocious treachery' ('perfidie lâche et féroce') and 'les sauvages' in the context of the spearthrowing incident; or 'les peuples sauvages' and 'the natural ferocity of their character' in the

\footnotetext{
${ }^{64}$ Péron and Freycinet, Voyage, vol. 2, 164, note a, my emphasis.

${ }^{65}$ Virey, Histoire naturelle du genre humain; White, An Account of the Regular Gradation in Man; see also Stocking, 'French Anthropology', 34.

${ }^{66}$ Péron and Freycinet, Voyage, vol. 1, 144. There is no indication in Péron's narrative that he actually saw any member of this 'race'.

${ }^{67}$ Ibid.
} 
context of his own fearful retreat from Maria Island. Other expressions are also countersigns of the mingled dread and outrage triggered by what I call local agency but Péron experienced as ‘the mercurial character' ('la mobilité du caractère') and 'perfidy’ of 'these fierce, rude tribes' ('ces peuplades féroces et grossières'). He complained that one group of men repaid French 'generosity' with a 'wild, menacing look' and a 'strained', 'malicious', 'treacherous' attitude ('quelque chose de constraint, de malveillant et de perfide') which, in Péron's eyes (though not mine), were captured in this engraving of one of Petit's Van Diemen's Land portraits (Figure 8$){ }^{68}$

\section{Insert Figure 8}

\section{Conclusion}

My empirical investigation has paid particular attention to the impression of referents on signifiers, specifically to traces of local agency in voyagers' representations: its overt signs in descriptions of observed (though rarely understood) Indigenous behaviour; and its opaque countersigns embedded in the language and tone of representations. Every genre of voyage text considered in this paper, from journal, to report, to narrative, is more or less thickly populated with Indigenous countersigns but they are especially notable in passages impregnated by strong emotion, as in the examples cited from Smith’s journal, Baudin’s ethnographic report, and Péron’s narrative.

The heuristic value of the concept of countersign is aptly illustrated by consideration of a much-debated theme in the historiography of these voyages: the dramatic mood swing in Péron’s narrative from sentimental approval of 'our good Diemenlanders' to scathing denunciation of 'these fierce men'. ${ }^{69}$ Modern scholarly explanations privilege the analysis of European discourses, as in Martin Staum’s discussion of Péron’s vacillation 'in the same narrative between the stereotypes of the noble and ignoble savage', or Miranda Hughes's account of Péron’s transition from Rousseauesque 'preconceptions' to equally a priori 'misconceptions' about savages. The assumed primacy of discourse is sometimes qualified by intimations of the textual impact of experience. Hughes called for (but did not provide) 'a

\footnotetext{
${ }^{68}$ Ibid., 236, 255, 282, 285, 287.

${ }^{69}$ Ibid., 231, 237.
} 
closer examination of the dynamics of the encounter ... and the manner in which interpretations were affected by actual confrontation' with Indigenous people. Rhys Jones stressed Péron's narrative contrivance but also noted the imprint of violent incidents which provoked such a 'sense of anger and of betrayal' that the 'euphoric descriptions in Péron's pen turned to disgust'. Howard Morphy attributed the deterioration in relations to worsening 'French attitudes' rather than Indigenous behaviour but acknowledged a temporal sequence from the spear-throwing episode to 'increasingly negative’ French descriptions. ${ }^{70}$

Yet serious consideration of local agency is rare in this literature. Patty O’Brien’s outrage at the 'rapacity of the French anthropological gaze' on Indigenous women blinded her almost entirely to traces of their agency which punctuate Péron’s narrative and helped fuel his racial misogyny. In contrast, Shino Konishi challenged the common notion - which she herself had shared - 'that the Tasmanians themselves played almost no role in shaping these derogatory European attitudes'. She reimagined Péron’s encounters as his ‘unrequited romance' with 'noble savages', blighted by their ‘disdain' and 'cool indifference to him'. She ended with a manifesto on the need to consider the 'power' or 'agency' of Indigenous people during early encounters. ${ }^{71}$ By enabling the identification of textual traces of the exercise of such power or agency, the concept of countersign supplies the building blocks for more informed, more subtle ethnohistories which decentre Europeans and personalize encounters as multifaceted, open-ended, embodied episodes, rather than essentialize them as generalized clashes of two opposed, homogeneous cultures.

This paper highlights important parallels and divergences in the national or professional vocabularies used by British and French travellers to refer to antipodean Indigenous people. In the process, it shows how old or emerging European conceptions of

\footnotetext{
${ }^{70}$ Hughes, 'Tall Tales', 73-5; R. Jones, 'Images of Natural Man', in Baudin in Australian Waters: the Artwork of the French Voyage of Discovery to the Southern Lands 1800-1804, edited by J. Bonnemains, E. Forsyth and B. Smith (Melbourne: Oxford University Press, 1988), 35-64 (45); idem, 'Philosophical Time Travellers', 753-4; Morphy, 'Encountering Aborigines', 151-2; Staum, Minerva’s Message, 167-8.

${ }^{71}$ Konishi, ‘François Péron', 5, 14, 15; P. O’Brien, 'Divine Browns and the Mighty Whiteman: Exotic Primitivism and the Baudin Voyage to Tasmania in 1802', Journal of Australian Studies 23:63 (1999):13-21 (21).
} 
human difference were confirmed, or ignored, or challenged, or constituted anew in practice by navigators and travelling naturalists. The published narrative of the naturalist Péron straddles the discursive transition under way in France at the end of the 18th century, from the deeply Eurocentric universalism of both main strands of the Enlightenment study of man to the divisive racialism which would dominate 19th-century anthropology. Indeed, several historians have made him a forerunner of that 'medicalized' physical anthropology. ${ }^{72}$ Whereas the deductive systems propounded by metropolitan savants were fairly immune to Indigenous presence, voyagers’ accounts, including Péron’s, were always susceptible to local agency and threatened by mismatches between presupposition and personal experience - the inadequacy of received vocabularies and concepts to comprehend highly varied human physical forms, lifestyles, and behaviours. The naval officers Flinders and Baudin were cautious pragmatists who used moderate, non-racialized language and ignored or were indifferent to the still embryonic, still heterodox mode of racial taxonomy which the natural history of man had recently begun enthusiastically to embrace. Yet their complacent ethnocentrism did not doubt that stadial differences were real, if not immutable, while their assured dignity of rank bespoke an ancient bias which had for centuries conflated foreign barbarians with domestic lower orders as wild, potential threats to civil society.

From the late 18th century, especially in France, natural history and stadial theory were co-opted by an embryonic science of race which conceived human diversity as biologically inherent, fixed, perhaps original, but also historical and hierarchical. The coupling of congealed racial and developmentalist theories with conjectural histories of migration and racial displacement condemned certain races - notably the Australians and the Tasmanians - to permanent occupation of the lowest rungs of the human ladder, denial of the capacity for progress, and the spectre of imminent extinction. Thus Darwin prophesied their doom and anticipated his famous principle in the narrative of his Beagle voyage, lamenting the 'mysterious agency' which appeared to dictate that, 'wherever the European has trod,

\footnotetext{
${ }^{72}$ Copans and Jamin, 'Présentation’, 37-9, 47-8, 66-7; Jones, 'Images of Natural Man’, 38-9; Stocking, 'French Anthropology', 32-4, 39-41
} 
death seems to pursue the aboriginal [...]—-the stronger always extirpating the weaker' ${ }^{73}$ Most metropolitan, colonial, and eventually Australian national opinion continued to profess such beliefs about Aboriginal people and their prospects during the next century and well beyond.

${ }^{73}$ C. Darwin, Narrative of the Surveying Voyages of His Majesty's Ships Adventure and Beagle, between the Years 1826 and 1836 [...], vol. 3, Journal and Remarks, 1832-1836 (London, 1839), 519-20; see also P. Broca, 'Des phénomènes d’hybridité dans le genre humain', Journal de la physiologie de l'homme et des animaux 2 (1859), 601-25; 3 (1860), 392-439 (413-14); A. R. Wallace, 'The Origin of Human Races and the Antiquity of Man Deduced from the Theory of "Natural Selection”“, Journal of the Anthropological Society of London 2 (1864), clviii-clxxxvii (clxv-clxv, clxvii). 


\section{Figures}

Figure 1: M. Flinders, 'General Chart of Terra Australis or Australia', detail. ${ }^{74}$

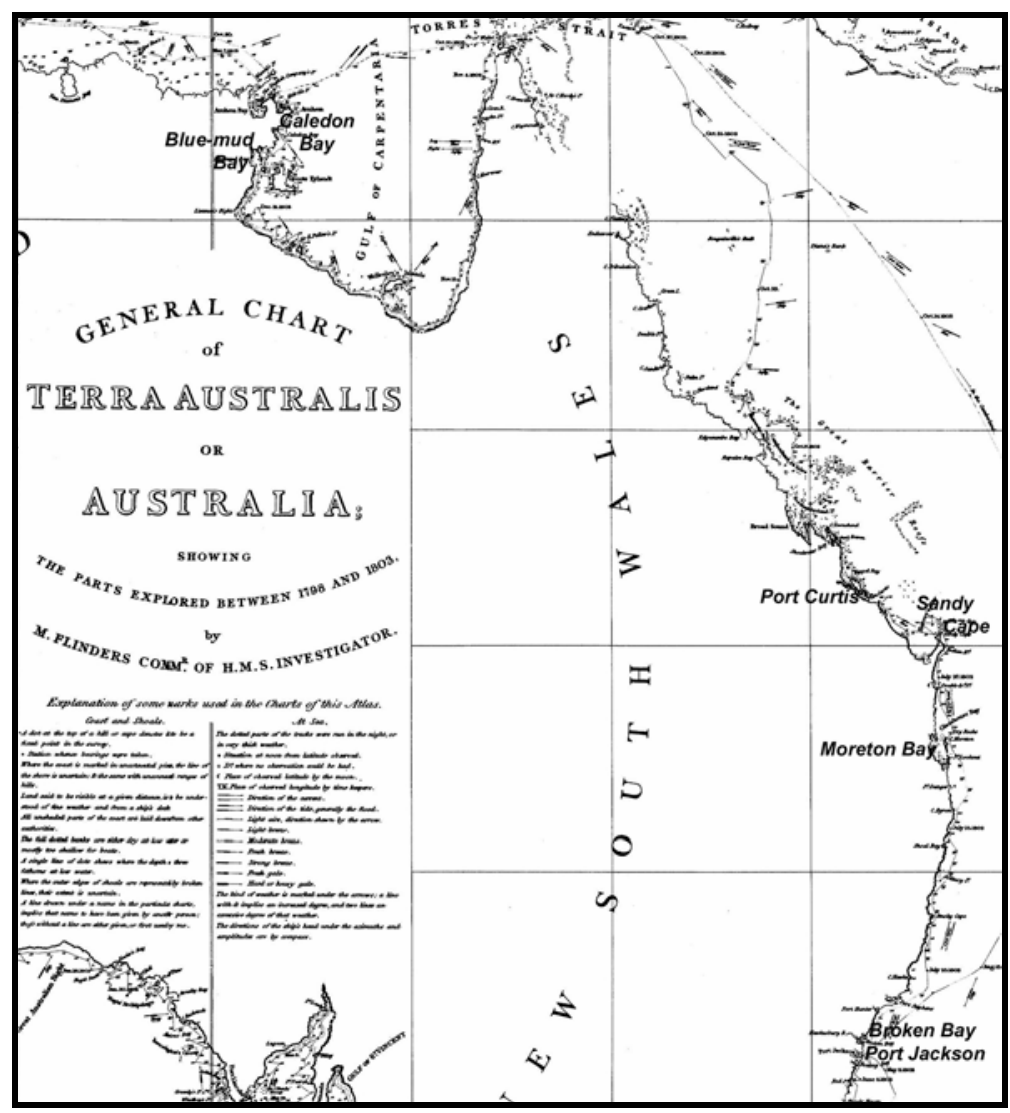

${ }^{74}$ M. Flinders, 'General Chart of Terra Australis or Australia; Showing the Parts Explored between 1798 and 1803', engraving, in idem, A Voyage to Terra Australis: [...] Prosecuted in the Years 1801, 1802, and 1803 in His Majesty's Ship the Investigator [...]. Atlas (London, 1814), plate 1, detail. Photograph B. Douglas. 
Figure 2: P. P. King, 'Boong-gar-ree Aboriginal of New South Wales 1819'. ${ }^{75}$

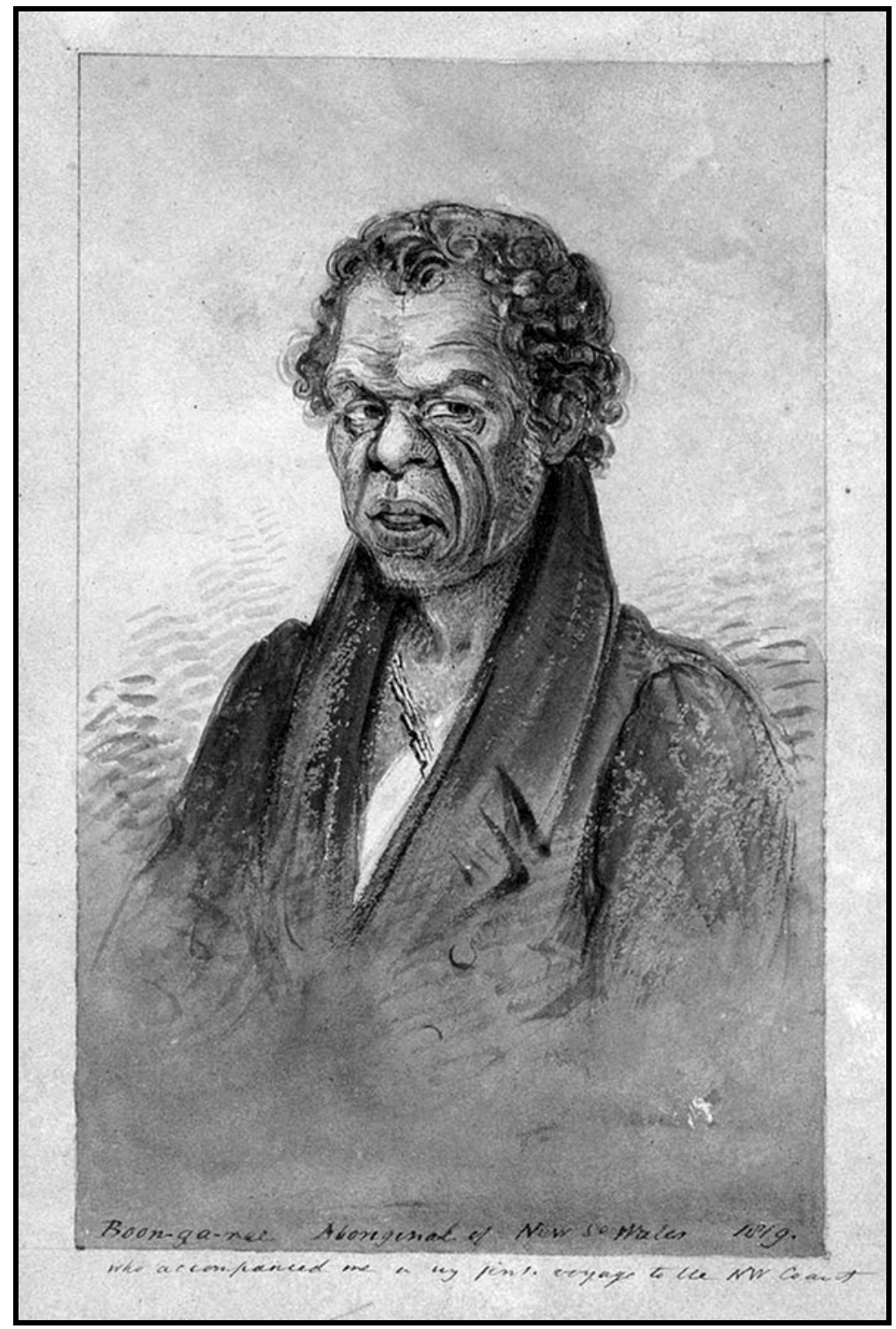

${ }^{75}$ P. P. King, 'Boon-gar-ree Aboriginal of New S ${ }^{\circ}$ Wales 1819 who Accompanied me on my first Voyage to the NW Coast', watercolour, in idem, 'Album of Drawings and Engravings, 1802-1902' (Sydney: State Library of New South Wales, PXC 767/48, online http://acms.sl.nsw.gov.au/item/itemDetailPaged.aspx?itemID=442570, accessed 30 June 2010), folio 48. 
Figure 3: W. Westall, [Blue Mud Bay, Body of a Native Shot on Morgan's Island]. ${ }^{76}$

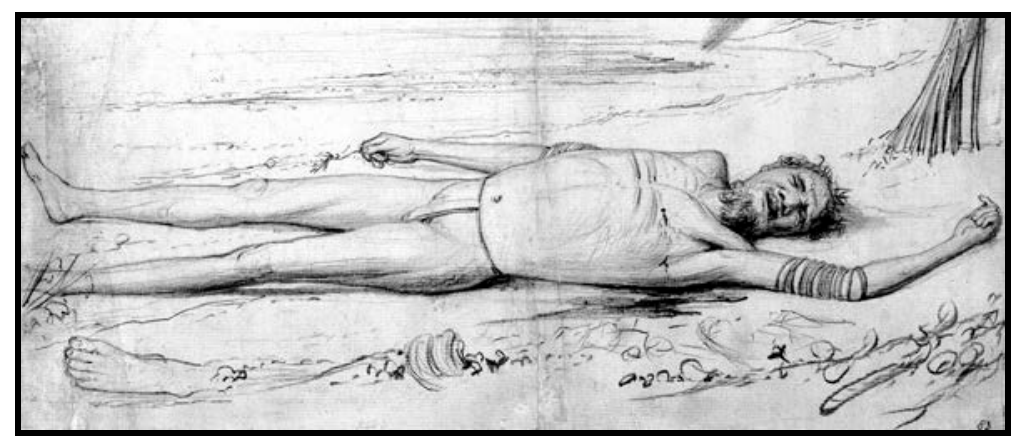

Figure 4: W. Westall, 'Woogah. Caledon Bay'.

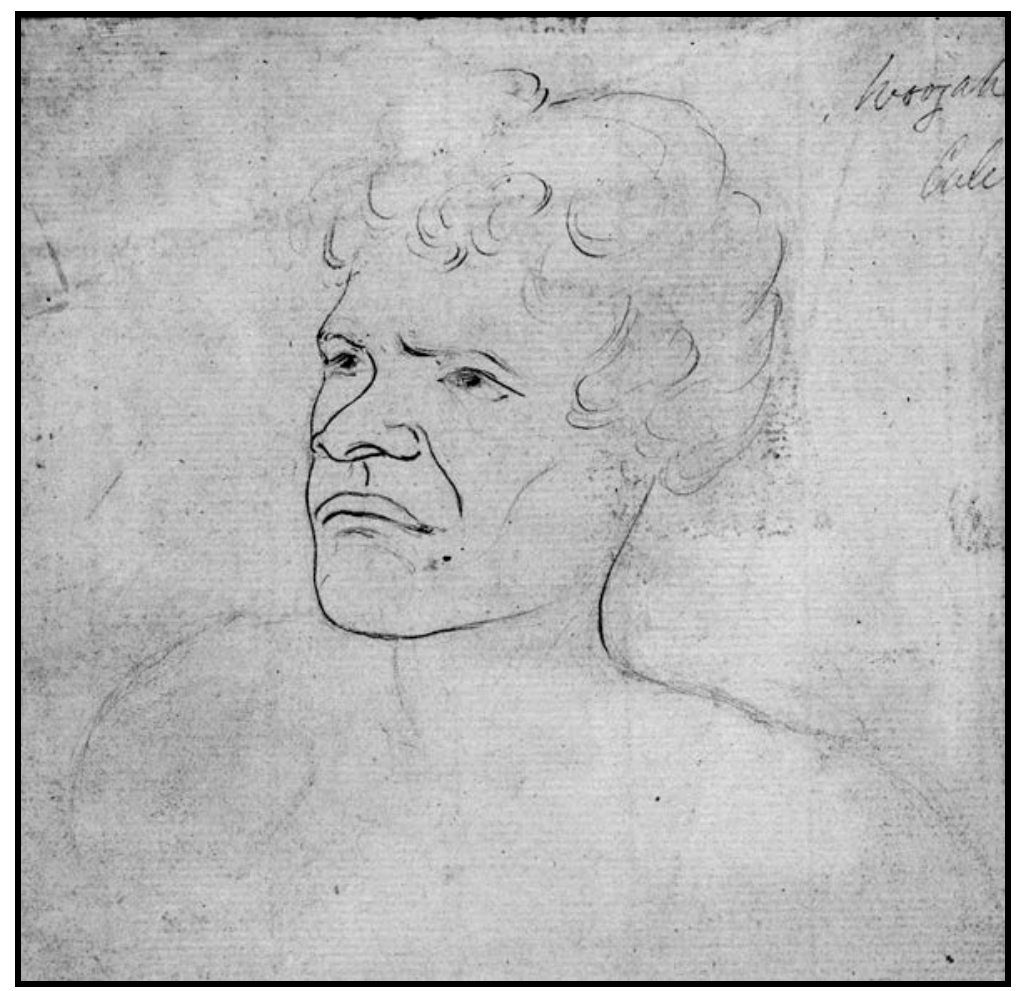

${ }^{76}$ W. Westall, [Blue Mud Bay, Body of a Native Shot on Morgan’s Island], pencil drawing, in idem, [Drawings, 1801-1803] (Canberra: National Library of Australia, PIC R4357 LOC Westall box 11, online http://nla.gov.au/nla.pic-an4565197, accessed 14 February 2011), box 11.

${ }^{77}$ W. Westall, 'Woogah. Caledon Bay’, pencil drawing, in idem, [Drawings, 1801-1803] (Canberra: National Library of Australia, PIC R4360 LOC Westall box 11, online http://nla.gov.au/nla.pic-an4564868, accessed 14 February 2011), box 11. 
Figure 5: L. de Saulces de Freycinet, 'Carte générale de la partie sud-est de la Terre de Diemen'. ${ }^{78}$

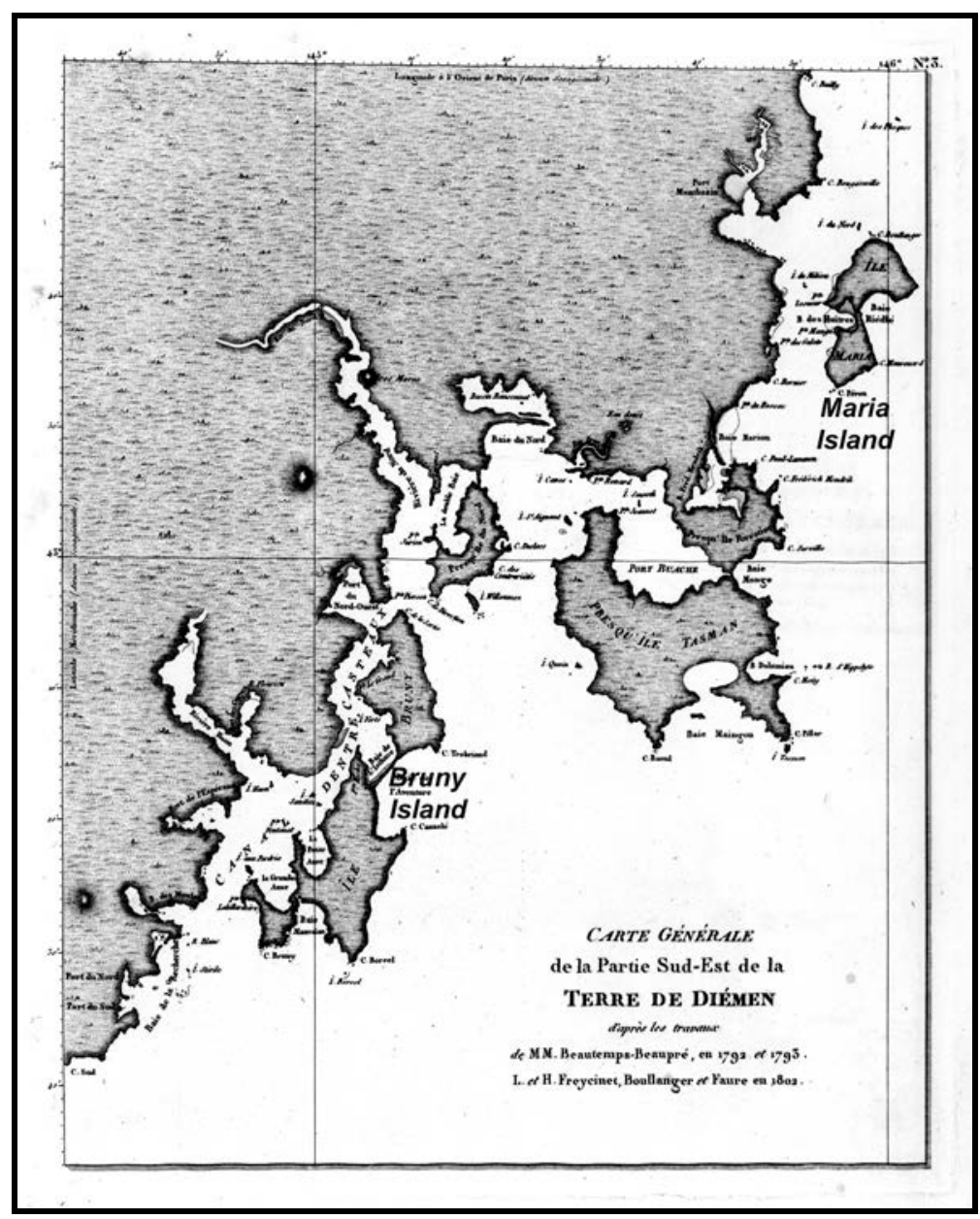

${ }^{78}$ L. de Saulces de Freycinet, 'Carte générale de la partie sud-est de la Terre de Diemen d’après les travaux de MM. Beautemps-Beaupré, en 1792 et 1793, L. et H. Freycinet, Boullanger et Faure en 1802', engraving, in idem, Voyage de découvertes aux terres australes [...] sur les corvettes le Géographe, le Naturaliste, et la goëlette le Casuarina, pendant les années 1800, 1801, 1802, 1803, et 1804. Historique. Atlas, $2^{\mathrm{e}}$ partie (Paris, 1811; Canberra: National Library of Australia, MAP RaA 1, online http://nla.gov.au/nla.map-raa1-s7, accessed 17 November 2009), plate 3. 
Figure 6: B. Roger after N.-M. Petit, 'Terre de Diémen. Parabéri' ${ }^{79}$

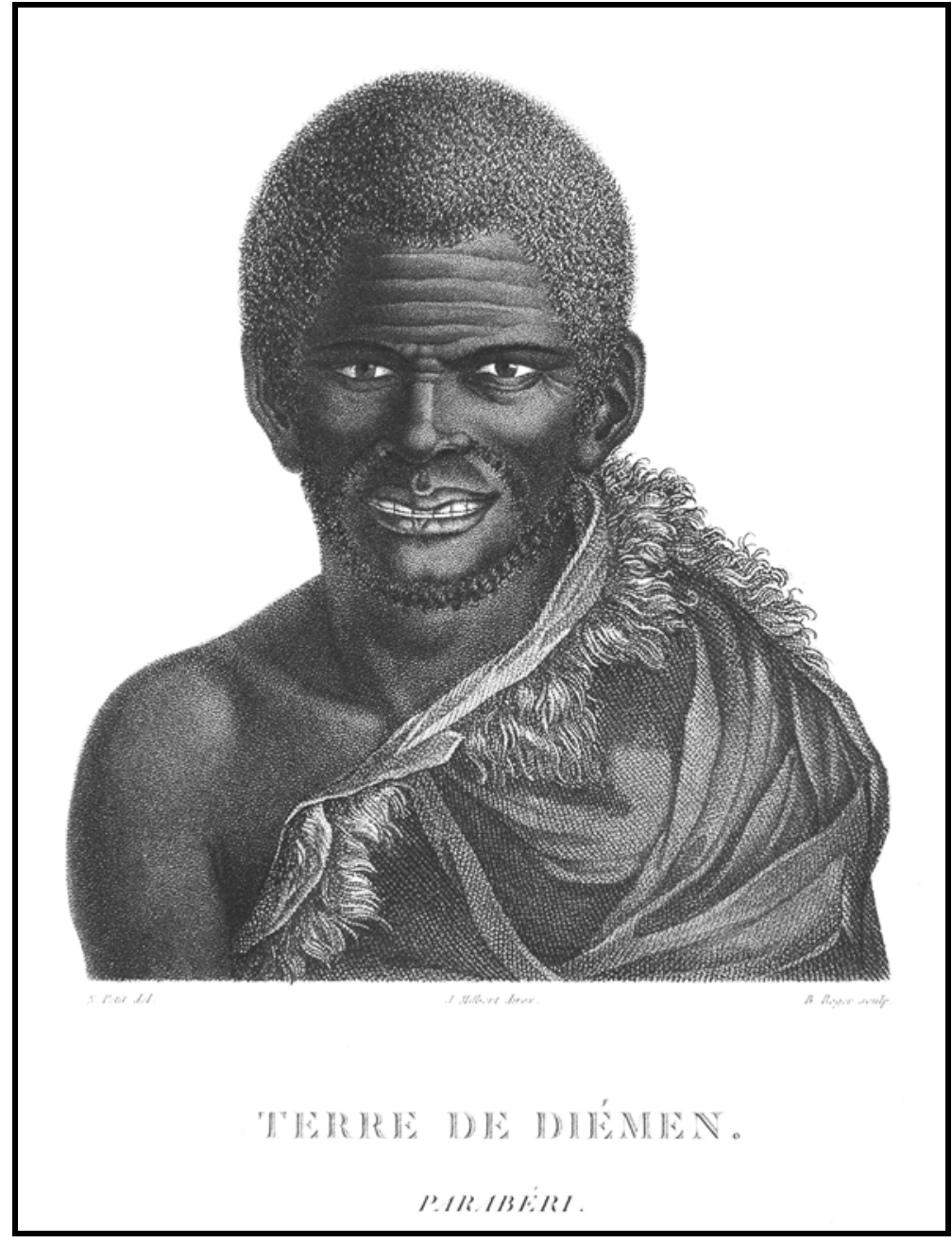

${ }^{79}$ B. Roger after N.-M. Petit, 'Terre de Diémen. Parabéri', engraving, in C.-A. Lesueur and N.-M. Petit, Voyage de découvertes aux terres australes exécuté par ordre de S.M.

l'Empereur et Roi. Partie Historique. Atlas (Paris, [1807]), plate 11. Photograph B. Douglas. 
Figure 7: B. Roger after N.-M. Petit, ‘Terre de Diémen. Bara-Ourou'. ${ }^{80}$

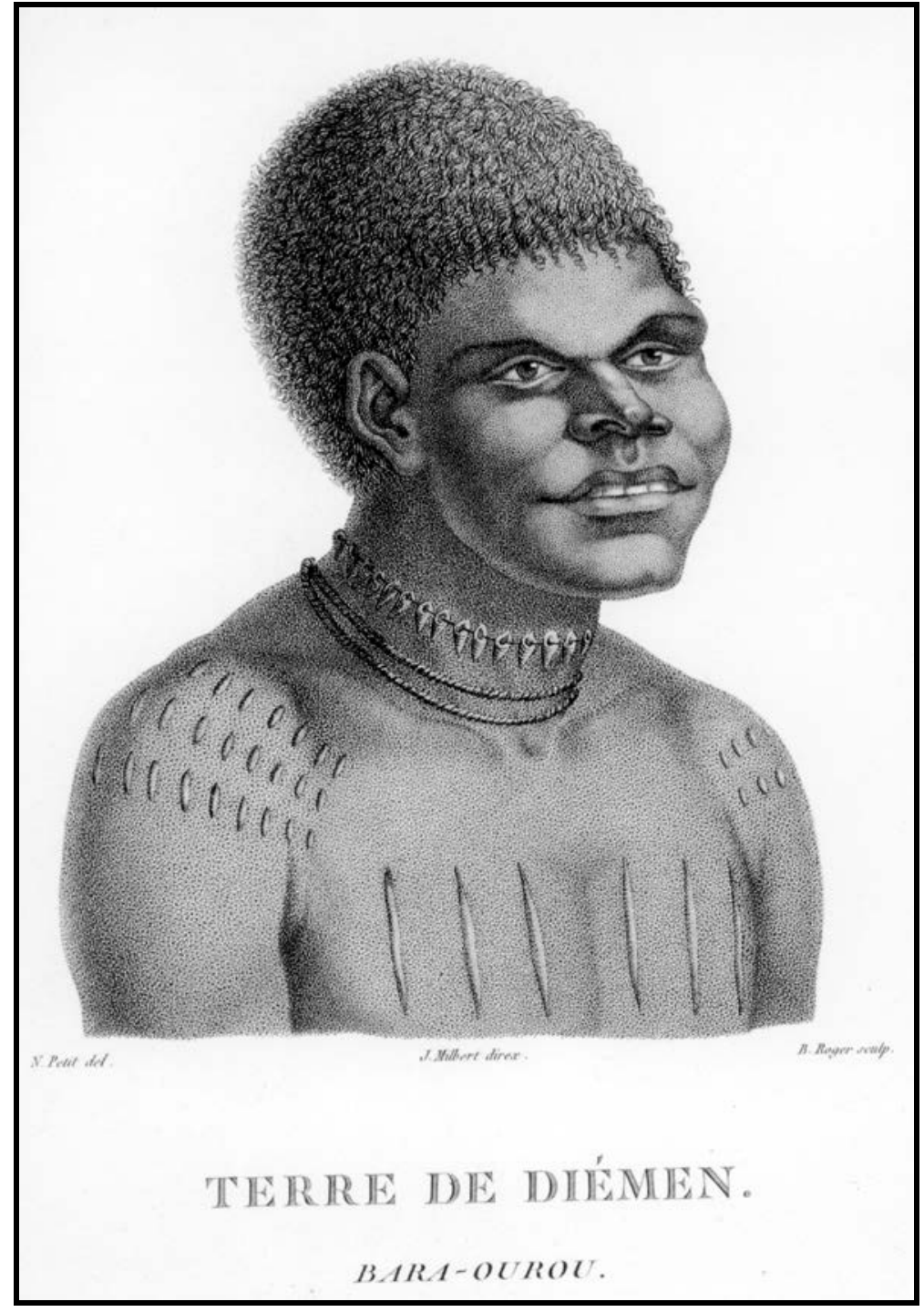

${ }^{80}$ B. Roger after N.-M. Petit, 'Terre de Diémen. Bara-Ourou', engraving, in C.-A. Lesueur and N.-M. Petit, Voyage de découvertes aux terres australes exécuté par ordre de S.M. l'Empereur et Roi. Partie Historique. Atlas (Paris, [1807]), plate 8. Photograph B. Douglas. 
Figure 8: B. Roger after N.-M. Petit, 'Terre de Diémen. Grou-Ăgără'. 81

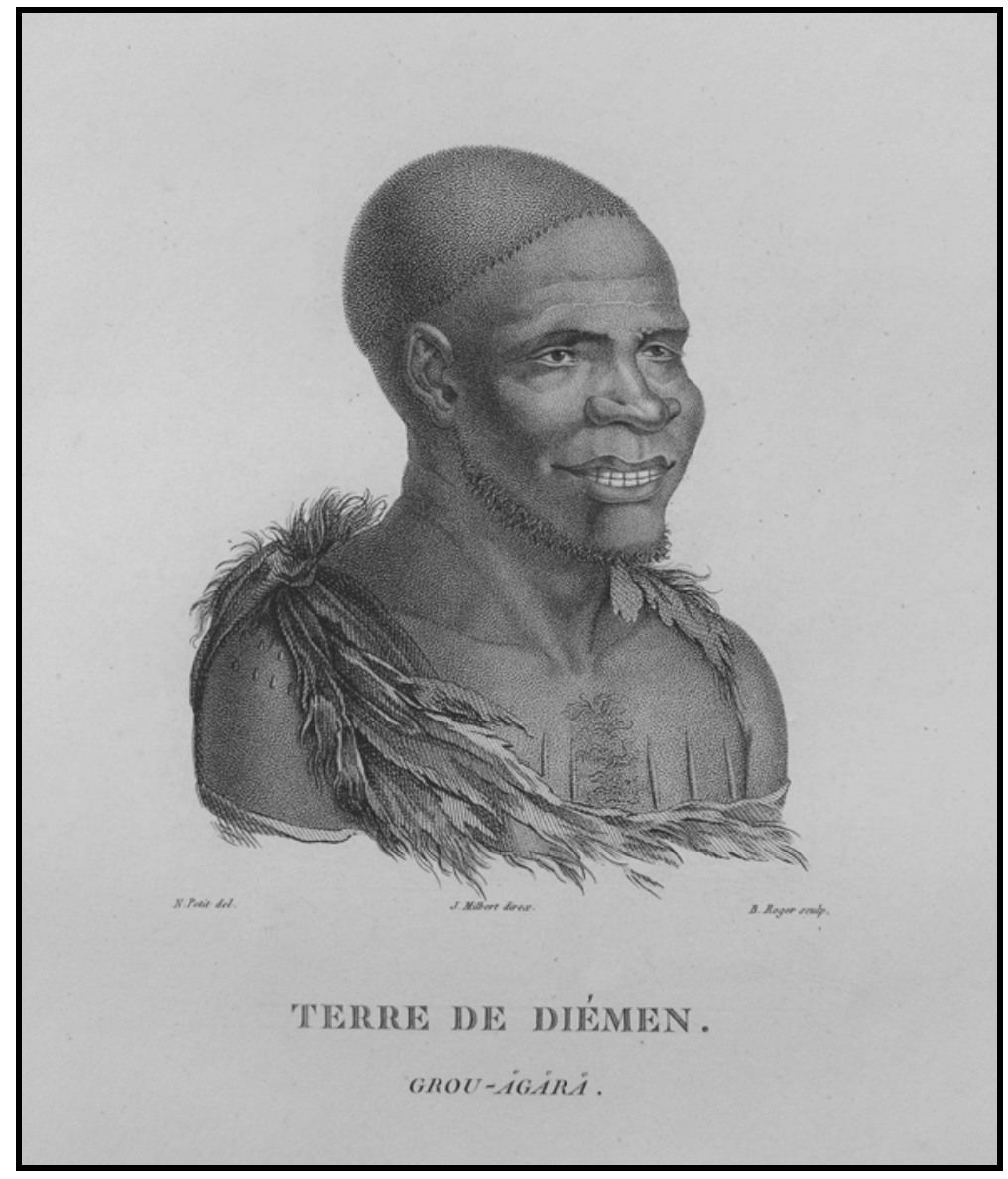

${ }^{81}$ B. Roger after N.-M. Petit, 'Terre de Diémen. Grou-Ăgără', engraving, in C.-A. Lesueur and N.-M. Petit, Voyage de découvertes aux terres australes exécuté par ordre de S.M. l'Empereur et Roi. Partie Historique. Atlas (Paris, [1807]), plate 10. Photograph B. Douglas. 